Mazur-Wierzbicka E., Poziom realizacji koncepcji zrównoważonego rozwoju w obszarze zmian klimatycznych $i$ energii w Polsce oraz Unii Europejskiej - analiza porównawcza, „Economics and Law", Polszakiewicz B., Boehlke J. (ed.), Vol. 13, No. 1/2014, pp. 195-210. DOI: http://dx.doi. org/10.12775/EiP.2014.015.

\author{
EWA MAZUR-WIERZBICKA*
}

\title{
POZIOM REALIZACJI KONCEPCJI ZRÓWNOWAŻONEGO ROZWOJU W OBSZARZE ZMIAN KLIMATYCZNYCH I ENERGII W POLSCE ORAZ UNII EUROPEJSKIEJ - ANALIZA PORÓWNAWCZA
}

STRESZCZENIE

Współcześnie problematyka związana ze zmianami klimatycznymi i pozyskiwaniem, wykorzystaniem energii jest szeroko dyskutowana tak na arenie międzynarodowej, jak i krajowej. Wyrazem obecności tej tematyki w dyskursie publicznym jest ujmowanie jej w wielu dokumentach międzynarodowych, krajowych (także tych o charakterze strategicznym). Stanowi ona także jeden z obszarów omawianych w kontekście zrównoważonego rozwoju poprzez zwrócenie uwagi m. in. na pozyskiwanie energii ze źródeł odnawianych, zużycie energii pierwotnej, czy też wielkość emisji gazów cieplarnianych. Także Unia Europejska w ramach dążenia do zrównoważonego rozwoju zaczęła przypisywać szczególne znaczenie wspomnianej problematyce.

Wobec powyższego za cel artykułu przyjęto próbę oceny poziomu realizacji koncepcji zrównoważonego rozwoju w obszarze dotyczącym zmian klimatycznych i energii w Polsce na tle krajów unijnych. Celowi pracy podporządkowano jej poszczególne części, w których przybliżono zrównoważony rozwój w zakresie zmian klimatycznych i energii w unijnych dokumentach strategicznych, oraz przeprowadzono analizę po-

Ewa Mazur-Wierzbicka, Uniwersytet Szczeciński, Wydział Nauk Ekonomicznych i Zarządzania, Katedra Organizacji i Zarządzania, ul. Mickiewicza 64, 71-110 Szczecin, tel.: +48914 441 985, e-mail: ewa.mazur-wierzbicka@wp.pl. 
równawczą Polski na tle krajów Unii Europejskiej w zakresie zmian klimatycznych i energii.

W artykule wykorzystano literaturę przedmiotu, dokumenty rządowe, zaś przeprowadzone analizy oparto o dane wtórne pochodzące z Eurostatu.

Słowa kluczowe: zrównoważony rozwój, zmiany klimatyczne i energia

Klasyfikacja JEL: Q4, Q56

\section{THE REALISATION LEVEL OF THE SUSTAINABLE DEVELOPMENT CONCEPTION IN CLIMATE CHANGE AND ENERGY RANGE IN POLAND AND EUROPEAN UNION COUNTRIES}

\section{SUMMARY}

The sustainable development issue since 60s of XX century is present on the international debate. One of the areas discussed in the sustainable development context is the climate change and energy and this in different ways for example taking energy from renewable energy sources, primary energy consumption or greenhouse gas emission. It goes probably from the connection between the energy sector and interference into the natural environment, the exploitation the natural sources and its high emission, what has a special meaning nowadays. that is why European Union starts to thing about special meaning of this issue, can we find this in its strategy documents.

The main aim of this work is the attempt assessment the level of realization the sustainable development in climate change and energy area in Poland and comparing that to the other European countries. The sustainable development in the climate change and energy has been shown in Polish and European countries strategy. The comparative analysis Poland to the other EU countries has been done.

The state documents and study literature have been used in this article. The comparative analysis were based on data form Eurostat.

Keywords: sustainable development, climate change and energy

JEL Classification: Q4, Q56

\section{WSTĘP}

Problematyka dotycząca zrównoważonego rozwoju od lat 60-tych XX wieku obecna jest $\mathrm{w}$ dyskursie publicznym na arenie międzynarodowej. Jednym z obszarów coraz częściej omawianych w kontekście zrównoważonego rozwoju są zmiany klimatyczne i energia. W obszarze tym zwraca się uwagę $\mathrm{m}$. in. na pozyskiwanie energii ze źródeł odnawianych, zużycie energii pierwotnej, czy 
też wielkość emisji gazów cieplarnianych. Wynika to niewątpliwie z faktu ścisłego powiązania sektora energetycznego $\mathrm{z}$ ingerencją $\mathrm{w}$ środowisko naturalne, eksploatowaniem zasobów naturalnych, jak również jego wysoką emisyjnością, co w dobie zauważalnych zmian klimatycznych nabiera szczególnego znaczenia. Stąd też Unia Europejska w ramach dążenia do zrównoważonego rozwoju zaczęła przypisywać szczególne znaczenie wspomnianej problematyce.

Wobec powyższego $\mathrm{w}$ niniejszym pracy podjęto próbę analizy poziomu realizacji koncepcji zrównoważonego rozwoju w obszarze dotyczącym zmian klimatycznych i energii w Polsce na tle krajów unijnych. Stanowi to zarazem zasadniczy cel artykułu. Za podstawowy horyzont czasowy analizy przyjęto lata 2004-2010. Jest to podyktowane uznaniem przez autorkę, iż zrównoważony rozwój można analizować wyodrębniając poszczególne etapy jego realizacji. Za etap pierwszy uznano lata 2001-2010 tj. od przyjęcia Strategii Zrównoważonego Rozwoju Unii Europejskiej do zakończenia realizacji Strategii Lizbońskiej. Etap drugi obejmuje lata 2011-2020 tj. czas, na który przewidziano realizację strategii „Europa 2020”. Z uwagi na fakt, iż Polska przystąpiła do Unii Europejskiej w 2004 roku, analizy rozpoczynają się od 2004 roku, natomiast kończą się wraz z zakończeniem etapu pierwszego w 2010 roku. Za tak wyznaczonym horyzontem czasowym przemawia także fakt braku znacznej ilości danych nawet dla 2012 roku, co uniemożliwiało kompleksową analizę kształtowania określonych wskaźników podczas wyznaczonego drugiego etapu badań.

Przeprowadzona w pracy analiza realizowana została w przekroju dwóch grup krajów tj. UE-10 (krajów, które wraz z Polską z dniem 1 maja 2004 roku stały się członkami Unii Europejskiej) oraz UE-15 (krajów „starej Unii”).

W opracowaniu wykorzystano literaturę przedmiotu, dokumenty rządowe, dane wtórne pochodzące z Eurostatu.

\section{ZRÓWNOWAŻONY ROZWÓJ W ZAKRESIE ZMIAN KLIMATYCZNYCH I ENERGII W UNIJNYCH DOKUMENTACH STRATEGICZNYCH}

W czerwcu 2001 roku na szczycie Rady Europejskiej w Göteborgu sformułowane w Strategii Lizbońskiej założenia zostały uzupełnione o elementy związane ze zrównoważonym rozwojem. Przyjęto wówczas dokument zatytułowany Zrównoważona Europa dla Lepszego Świata: Strategia Zrównoważonego Rozwoju Unii Europejskiej ${ }^{1}$. W strategii dokonano integracji celów ekonomicz-

\footnotetext{
${ }^{1}$ Komisja Europejska, Zrównoważona Europa dla Lepszego Świata: Strategia Zrównoważonego Rozwoju Unii Europejskiej, COM(2001)264, Bruksela 2001.
} 
nych (dobrobyt ekonomiczny), społecznych (równość i spójność społeczna) i środowiskowych (ochrona środowiska). Zwrócono w niej także uwagę pośód różnych problemów na te, dotyczące zmian klimatycznych, wykorzystania energii. Uznano za konieczne w perspektywie długookresowej ograniczenie zmian klimatycznych oraz podejmowanie działań prowadzących do wzrostu zużycia czystej energii, w tym²:

- założono, że dotyczy to zarówno krajów unijnych, jak też innych krajów wysoko uprzemysłowionych,

- przyjęto, że Unia Europejska powinna dążyć do redukcji emisji gazów cieplarnianych średnio o $1 \% \mathrm{w}$ ciagu roku ponad poziom z 1990 roku aż do 2020 roku.

Tak sformułowane cele i wyzwania miały swoje podłoże w istotnym zagrożeniu upatrywanym $\mathrm{w}$ tym, iż emisje gazów cieplarnianych $\mathrm{z}$ działalności człowieka przyczyniają się do globalnego ocieplenia. Z kolei zmiany klimatu mogą prowadzić do ekstremalnych zjawisk meteorologicznych (powodzie, huragany), których skutki dla infrastruktury, własności, zdrowia i przyrody mogą być bardzo poważne ${ }^{3}$.

W czerwcu 2006 roku Rada Europejska po uprzednim dokonaniu weryfikacji istniejącej strategii zrównoważonego rozwoju przyjęła Odnowioną Strategię Zrównoważonego Rozwoju Unii Europejskiej (OSZR UE) ${ }^{4}$. Za jeden z czterech fundamentalnych celów uznano ochronę środowiska, czyli skupienie się na poprawie jakości środowiska naturalnego, racjonalnym wykorzystywaniu zasobów naturalnych, przeciwdziałaniu zanieczyszczeniu środowiska i ograniczaniu wielkości tego zjawiska, propagowaniu zrównoważonej konsumpcji i produkcji ${ }^{5}$. Wpisywały się w to także działania dotyczące zmian klimatycznych i energii, które uznano za jedno z siedmiu podstawowych wyzwań w obszarze polityki gospodarczej, społecznej i środowiskowej ${ }^{6}$. Za cel ogólny tego wyzwania przyjęto ograniczenie zmian klimatu oraz ich kosztów i negatywnych skutków, jakie obciążają społeczeństwo i środowisko naturalne ${ }^{7}$.

2 Ibidem, s. 11-14.

${ }^{3}$ Ibidem, s. 3-4.

${ }^{4}$ Rada Unii Europejskiej, Odnowiona Strategia Unii Europejskiej dotycząca Trwatego Rozwoju, Bruksela 10917/2006, s. 1.

5 Ibidem, s. 3-4.

${ }^{6}$ Oprócz tego wyzwania sześć pozostałych stanowiły: zrównoważony transport, zrównoważona konsumpcja i produkcja, ochrona i gospodarowanie zasobami naturalnymi, zdrowie publiczne, integracja społeczna, demografia i migracja, wyzwania związane z globalnym ubóstwem i zrównoważonym rozwojem.

${ }^{7}$ Rada Unii Europejskiej, op. cit., s. 7. 
Do OSZR UE nawiązuje bezpośrednio obowiązujący obecnie zestaw wskaźników zrównoważonego rozwoju. Wskaźniki pogrupowano w 10 obszarów tematycznych (dziedzin), które są odzwierciedleniem 7 kluczowych wyzwań strategii. Wśród nich istotne miejsce zajmują wskaźniki dotyczące dziedziny 6. tj. „Zmiany klimatu i energia” (tabela 1).

Tabela 1. Podział wskaźników zrównoważonego rozwoju Unii Europejskiej w dziedzinie „Zmiany klimatu i energia"

\begin{tabular}{|c|c|c|c|}
\hline DZIEDZINA & POZIOM 1 - WSKAŹNIKI WIODACEE & POZIOM 2 WSKAŹNIKI OPERACYJNE & $\begin{array}{c}\text { POZIOM } 3 \text { WSKAŹNIKI OBJAŚ- } \\
\text { NIAJĄCE }\end{array}$ \\
\hline \multirow{4}{*}{$\begin{array}{c}\text { Dziedzina } 6 \\
\text { Zmiany klimatu } \\
\text { i energia }\end{array}$} & \multirow{4}{*}{$\begin{array}{l}\text { Emisja gazów cieplarnianych } \\
\text { Udział energii odnawialnej } \\
\text { w końcowym zużyciu ener- } \\
\text { gii brutto } \\
\text { Zużycie energii pierwotnej }\end{array}$} & \multicolumn{2}{|c|}{ Zmiana klimatu } \\
\hline & & $\begin{array}{c}\text { Emisja gazów cieplarnianych } \\
\text { według sektorów }\end{array}$ & $\begin{array}{c}\text { Intensywność emisji gazów cie- } \\
\text { plarnianych związana ze zuży- } \\
\text { ciem energii }\end{array}$ \\
\hline & & \multicolumn{2}{|c|}{ Energia } \\
\hline & & Zależność energetyczna & $\begin{array}{c}\text { Zużycie krajowej energii brutto } \\
\text { Produkcja energii elektrycznej } \\
\text { ze źródeł odnawialnych } \\
\text { Kogeneracja }\end{array}$ \\
\hline
\end{tabular}

Źródło: Opracowanie własne na postawie: Eurostat, http://epp.eurostat.ec.europa.eu/portal/page/portal/sdi/indicators (12.12.2013).

Kolejnym istotnym dokumentem unijnym, stanowiącym kontynuację Strategii Lizbońskiej (w znacznym stopniu korzystającym z jej doświadczeń) jest Strategia na rzecz inteligentnego i zrównoważonego rozwoju sprzyjającego wtaczeniu spotecznemu - „Europa 2020”8 (strategia „Europa 2020”). Zakłada ona inteligentny i zrównoważony rozwój, zwiększoną ilość miejsc pracy, poprawę standardu życia, co powinno sprzyjać włączeniu społecznemu, określać kierunek rozwoju społeczeństw. Strategia ta opiera się na trzech filarach którymi są : wzrost inteligentny, wzrost zrównoważony, wzrost sprzyjający włączeniu społecznemu, z którymi korespondują odpowiednie inicjatywy przewodnie. W ramach zrównoważonego wzrostu wyróżniono dwie inicjatywy tj. ${ }^{10}$ :

Europa efektywnie korzystająca $z$ zasobów: Działania na rzecz uniezależnienia wzrostu gospodarczego od wykorzystania zasobów oraz transformacji

${ }^{8}$ Komisja Europejska, Europa 2020. Strategia na rzecz inteligentnego i zrównoważonego rozwoju sprzyjającego wtaczeniu spotecznemu, COM (2005)2020, Bruksela 2010.

9 T. Gabrusewicz, Pomiar w zrównoważonym rozwoju - w poszukiwaniu wspólnej koncepcji, [w:] W. Czternasty (red.), Gospodarka Polski po akcesji do Unii Europejskiej. Wymiar finansowy, Zeszyt Naukowy Uniwersytetu Ekonomicznego w Poznaniu, Nr 207/2011, s. 7-19.

${ }^{10}$ Komisja Europejska, Europa 2020..., op. cit., s. 14-22. 
w kierunku gospodarki niskoemisyjnej, w większym stopniu wykorzystującej potencjał, jaki dają odnawialne źródła energii.

Polityka przemysłowa na rzecz ekologicznego rozwoju: Zwiększanie konkurencyjności unijnego sektora przemysłu w warunkach pokryzysowych, wsparcie przedsiębiorczości i rozwój nowych umiejętności.

W ramach pierwszej inicjatywy rozpatrywać należy kwestie związane ze zmianami klimatycznymi i energią. W strategii sformułowano pakiet pięciu celów głównych, wśród których znalazły się także te, dotyczące pakietu energetyczno-klimatycznego (nie były one ujęte liczbowo w Strategii Lizbońskiej). Wartości docelowe zostały określone dla całej Unii Europejskiej (tabela 2).

Tabela 2. Główne cele i wskaźniki strategii „Europa 2020” w zakresie tematyki zmiany klimatu i energia

\begin{tabular}{|c|c|}
\hline CELE GŁÓWNE & WSKAŹNIKI GŁÓWNE \\
\hline \multirow{3}{*}{$\begin{array}{c}\text { Osiągnięcie celów „20/20/20” w zakresie klimatu i ener- } \\
\text { gii: } \\
\text { zmniejszenie emisji gazów cieplarnianych o 20\% w po- } \\
\text { równaniu z } 1990 \text { roku } \\
\text { zwiększenie do 20\% udziału energii odnawialnej } \\
\text { w ogólnych zużyciu energii } \\
\text { zwiększenie efektywności energetycznej o 20\%* }\end{array}$} & Emisja gazów cieplarnianych $(1990=100)$ \\
\hline & $\begin{array}{l}\text { Udział energii ze źródeł odnawialnych w końcowym zu- } \\
\text { życiu energii brutto }\end{array}$ \\
\hline & Zużycie energii pierwotnej** \\
\hline
\end{tabular}

* Unia Europejska zdecydowana jest podjąć decyzję o osiągnięciu do 2020 roku 30-procentowej redukcji emisji w porównaniu z poziomami z 1990 roku, o ile inne kraje rozwinięte zobowiążą się do porównywalnych redukcji emisji, a kraje rozwijające się wniosą wkład na miarę swoich zobowiązań i możliwości.

** Wskaźnik zastąpił dotychczas stosowany „Energochłonność gospodarki”.

Źródło: Komisja Europejska, Europa 2020. Strategia na rzecz inteligentnego i zrównoważonego rozwoju sprzyjającego włączeniu społecznemu, COM (2005)2020, Bruksela 2010, s. 12 i n.

Główne cele strategii „Europa 2020” zgodnie z zaleceniami Komisji Europejskiej zostały przełożone na cele krajowe i ujęte w dokumentach zwanych Krajowymi Programami Reform, gdzie określono również metody ich realizacji, jak też środki niezbędne do ich osiągnięcia.

\section{PORÓWNANIE WSKAŹNIKÓW W OBSZARZE ZMIAN KLIMATYCZNYCH I ENERGII W POLSCE ORAZ UNII EUROPEJSKIEJ}

W obliczu zachodzących zmian ważnym wydaje się przeprowadzenie analizy poziomu realizacji koncepcji zrównoważonego rozwoju w obszarze dotyczącym zmian klimatycznych i energii w Polsce na tle dwóch grup krajów tj. UE-10 oraz UE-15. Do przeprowadzenia analizy wykorzystano wskaźniki wiodące dziedziny 6 zrównoważonego rozwoju (tj. z poziomu I), dla uzupełnienia treści posłużono się także wskaźnikami z poziomu II i III o więk- 
szym stopniu szczegółowości. Analiza dotyczy pierwszego etapu realizacji zrównoważonego rozwoju, który dla Polski obejmuje lata 2004-2010 tj. od przystąpienia Polski do Unii Europejskiej do zakończenia realizacji Strategii Lizbońskiej. Jest ona uzupełniona o analizę danych za dwa pierwsze lata etapu drugiego, przypadającego na czas obowiązywania strategii „Europa 2020”, w przypadku której wykorzystane zostaną wskaźniki ujęte w tej strategii dotyczące analizowanych zagadnień.

Podstawę dla określenia średniego poziomu danej miary w grupie krajów w danym momencie (w granicach wyznaczanych przez przyjęty horyzont czasowy) stanowiła wartość jej mediany. Dodatkowo dla czytelności przedstawionych na wykresach danych dokonano przekształcenia destymulant w stymulanty.

\subsection{ANALIZA KSZTAŁTOWANIA SIĘ WSKAŹNIKÓW WIODĄCYCH W DZIEDZINIE ZMIANY KLIMATYCZNE I ENERGIA}

W czołówce najmniejszego zużycia energii pierwotnej ${ }^{11}$ w 2004 roku w grupie krajów UE-25 uplasowały się trzy kraje z grupy UE-10, tj. Malta, Cypr oraz Łotwa, kolejną pozycję zajmował Luksemburg jako kraj o najniższym zużyciu energii pierwotnej w grupie krajów UE-15. W grupie krajów UE-10, najwyższy poziom zużycia energii pierwotnej zarejestrowano w Polsce i Czechach (wielkość wskaźnika w Czechach była o 50\% mniejsza w porównaniu do analogicznego dla Polski).

W 2010 roku zarówno kraje o najniższym zużyciu energii pierwotnej, jak i najwyższym w grupach krajów UE-10 i UE-15 utrzymały swoje pozycje z 2004 roku. W większości krajów (szczególnie z grupy UE-15) nastąpił spadek wielkości omawianego wskaźnika. $Z$ wykresu 1 wynika, że wielkość wskaźnika zużycia energii pierwotnej w Polsce na tle wielkości median tożsamego wskaźnika dla grup krajów UE-10 i UE-15 w latach: 2004, 2010 wypada niekorzystnie.

11 Energia pierwotna - to suma energii zawartej w pierwotnych nośnikach energii (węgiel kamienny i brunatny, ropa naftowa, gaz ziemny, torf, drewno opałowe, paliwa odpadowe stałe roślinne i zwierzęce, odpady przemysłowe stałe i ciekłe, odpady komunalne, inne surowce wykorzystywane do celów energetycznych, energia wody, wiatru, energia słoneczna, geotermalna, z biomasy). Zużycie energii pierwotnej obejmuje zużycie nośników energii pierwotnej, a także odzysk, saldo wymiany, bunkier i zmianę zapasów pochodnych nośników energii w tysiącach ton oleju ekwiwalentnego (wg metodologii Eurostatu). Tona oleju ekwiwalentnego (toe) jest to równoważnik jednej metrycznej tony ropy naftowej o wartości opałowej równej 10 tys. kilokalorii na kilogram $(10000 \mathrm{kcal} / \mathrm{kg})$. 
Analiza kształtowania się kolejnego wskaźnika wiodącego pokazuje, że udział energii odnawialnej w końcowym zużyciu energii brutto w 24. na 25. analizowanych krajach Unii Europejskiej wzrastał. Jedynym wyjątkiem, kiedy to w perspektywie siedmiu lat obserwowany był spadek wielkości tego wskaźnika była Łotwa. W 2004 roku w grupie krajów UE-10 największy udział energii odnawialnej w końcowym zużyciu energii brutto wykazywała Łotwa (32,8\%), najniższy - Malta (0,1\%). W grupie krajów UE-15 wskaźnik ten przyjmował najwyższy poziom dla Szwecji (38,7\%), najniższy zaś dla Luksemburga $(0,1 \%)$.

Wielkość mediany analizowanego wskaźnika w 2010 roku w stosunku do 2004 roku dla grupy krajów UE-10 była większa od poziomu analizowanego wskaźnika dla Polski. Dla grupy krajów UE-15 wielkość mediany udziału energii odnawialnej w końcowym zużyciu energii brutto w 2010 roku oraz w 2004 roku była większa zarówno w stosunku do wielkości mediany dla grupy krajów UE-10, jak i do wielkości analizowanego wskaźnika dla Polski. Wielkości median udziału energii odnawialnej w końcowym zużyciu energii brutto dla grupy krajów UE-10 oraz UE-15 w latach 2004 i 2010, wykazywały tendencję wzrostową. Wielkość analizowanego wskaźnika dla Polski kształtowała się poniżej wielkości median dla obu analizowanych grup krajów.

Dla wskaźnika wiodącego - emisja gazów cieplarnianych ${ }^{12}$ znaczącą rolę odegrały zapisy zamieszczone w protokole z Kioto. Zarówno w 2004 roku, jak i w 2010 roku wielkości największe oraz najmniejsze analizowanego wskaźnika uzyskiwały te same kraje (w grupie krajów UE-10 największa wielkość - Słowenia, najmniejsza - Łotwa; w grupie krajów UE-15 największa wielkość - Hiszpania, najmniejsza - Niemcy). W większości analizowanych krajów UE-25 w 2010 roku w porównaniu do 2004 roku, nastąpił spadek emisji gazów cieplarnianych. Jedynie na Łotwie, w Estonii oraz w Polsce, czyli w krajach z grupy UE-10, odnotowano jej wzrost. Należy jednak podkreślić, że Polska na tle pozostałych analizowanych krajów UE-25 (jak też w porównaniu $\mathrm{z}$ wyodrębnionymi grupami krajów UE-10 i UE-15) wykazywała stosunkowo niewysoką emisję gazów cieplarnianych.

${ }^{12}$ Wskaźnik określa całkowitą roczną emisję gazów cieplarnianych wytworzonych przez człowieka („Koszyk z Kioto”) w odniesieniu do roku bazowego Kioto (dla Polski 1988 = 100) $\mathrm{z}$ wyłączeniem emisji pochodzącej z lotnictwa międzynarodowego i międzynarodowego transportu morskiego oraz związanej z użytkowaniem gruntów, zmiany użytkowania gruntów i leśnictwa (definicja przyjęta za Głównym Urzędem Statystycznym). 
2004
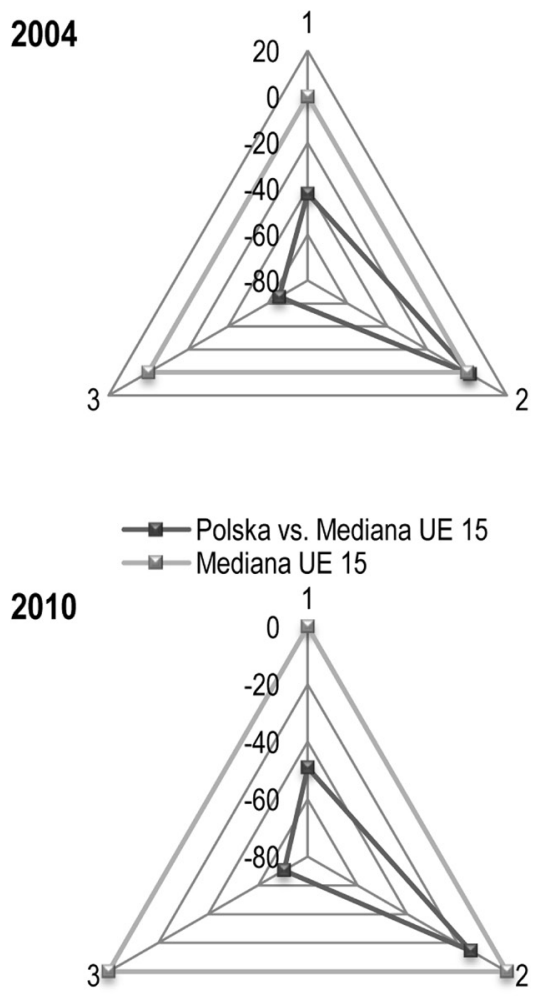

$\because$ Polska vs. Mediana UE 15 $\longrightarrow$ - Mediana UE 15
2004

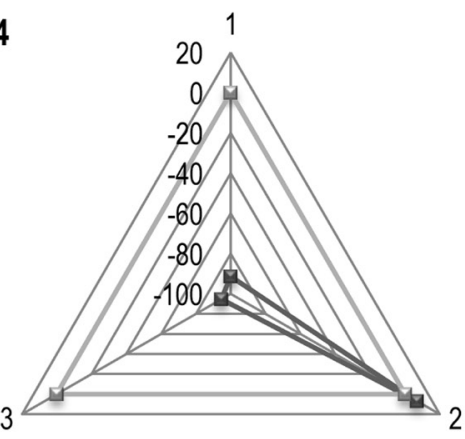

2010

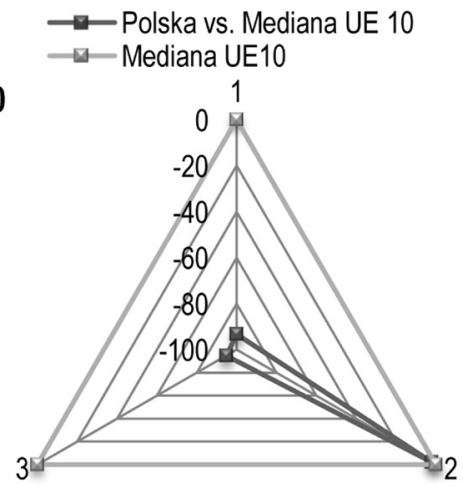

$\rightarrow$ Polska vs. Mediana UE 10 $\longrightarrow$ Mediana UE 10

1. Zużycie energii pierwotnej (tys. ton toe)

2. Udział energii odnawialnej w końcowym zużyciu energii brutto (\%)

3. Emisja gazów cieplarnianych (1 000 ton ekwiwalentu $\left.\mathrm{CO}_{2}\right)^{13}$

Wykres 1. Porównanie kształtowania się wskaźników wiodących dziedziny 6. zrównoważonego rozwoju dla Polski z wielkościami median tożsamych wskaźników dla grup krajów UE-10 i UE-15 w latach 2004 i 2010

Źródło: Opracowanie własne na podstawie: Eurostat, http://epp.eurostat.ec.europa.eu/portal/page/portal/sdi/indicators (12.12.2013).

\subsection{ANALIZA KSZTAŁTOWANIA SIĘ WSKAŹNIKÓW OPERACYJNYCH I OBJAŚNIAJĄCYCH W DZIEDZINIE ZMIANY KLIMATYCZNE I ENERGIA}

Pogłębiona analiza przy wykorzystaniu wskaźników z II i III poziomu z zakresu zmian klimatycznych wskazuje na dwa zasadnicze obszary. Pierw-

${ }^{13}$ W zestawieniach nie ujęto Cypru i Malty ze względu na brak danych w całym analizowanym okresie. 
szym jest emisja gazów cieplarnianych według sektorów, drugim zaś intensywność emisji gazów cieplarnianych związana ze zużyciem energii (Index 2000 = 100). Jak pokazano na wykresie 2 zarówno w 2004 roku, jak też w 2010 roku wielkości wskaźników emisji gazów cieplarnianych we wszystkich analizowanych sektorach dla Polski były mniejsze od wielkości median tożsamych wskaźników zarówno dla grupy krajów UE-10, jak i dla grupy krajów UE-15. Była to sytuacja bardzo korzystna.

2004
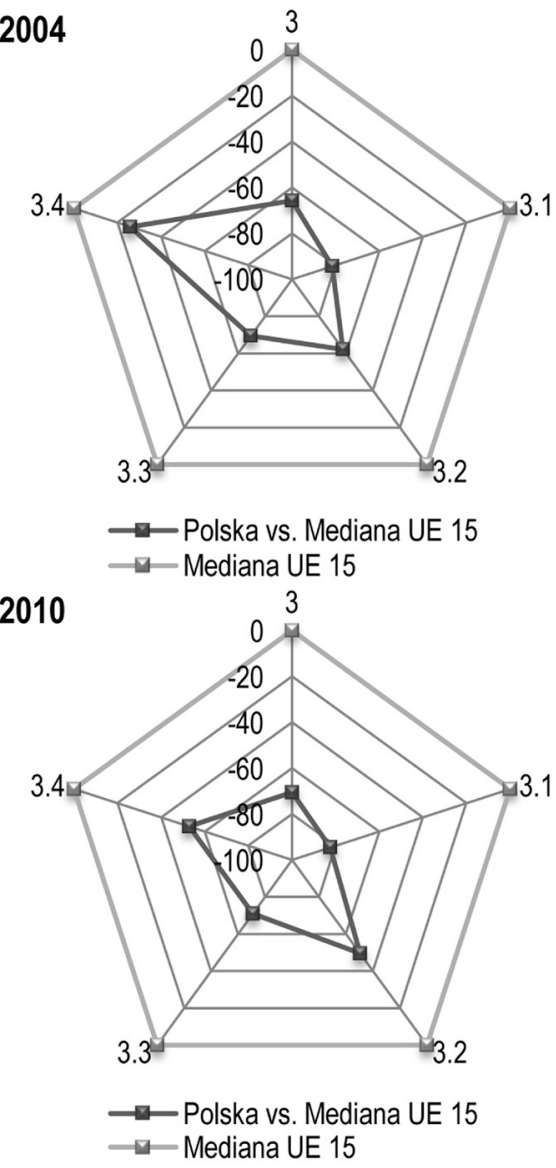
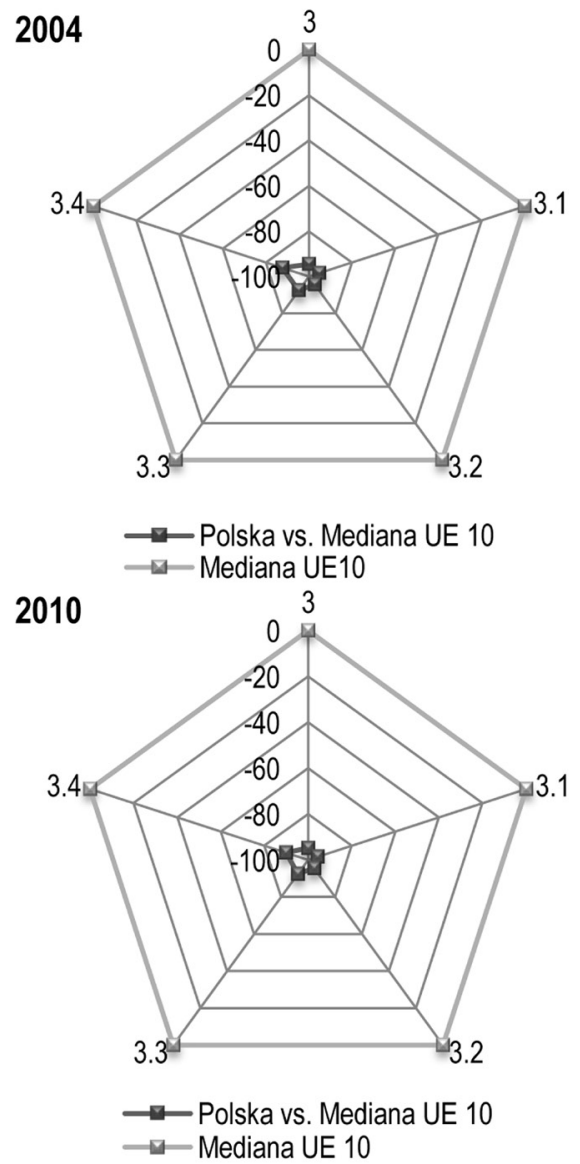

3. Całkowita emisja gazów cieplarnianych według sektorów (1 000 ton ekwiwalentu $\mathrm{CO}_{2}$ )

3.1. Emisja gazów cieplarnianych według sektorów - energetyka ( 1000 ton ekwiwalentu $\mathrm{CO}_{2}$ )

3.2 Emisja gazów cieplarnianych według sektorów - przemysł i budownictwo (1 000 ton ekwiwalentu $\mathrm{CO}_{2}$ )

3.3. Emisja gazów cieplarnianych według sektorów- rolnictwo (1 000 ton ekwiwalentu $\mathrm{CO}_{2}$ )

3.4. Emisja gazów cieplarnianych według sektorów- transport (1 000 ton ekwiwalentu $\mathrm{CO}_{2}$ )

Wykres 2. Porównanie kształtowania się emisji gazów cieplarnianych według sektorów dla Polski z wielkościami median tożsamych wskaźników dla grup krajów UE-10 i UE-15 w latach 2004 i 2010 Źródło: Opracowanie własne na podstawie: Eurostat, http://epp.eurostat.ec.europa.eu/portal/page/portal/sdi/indicators (12.12.2013). 
Równie korzystna sytuacja wystąpiła w przypadku kształtowania się wskaźnika - intensywność emisji gazów cieplarnianych związana ze zużyciem energii (Index 2000 = 100). W 2010 roku w porównywaniu do 2004 roku Polska odnotowała spadek wielkości tego wskaźnika. Zarówno w 2004 roku, jak też w 2010 roku wielkość analizowanego wskaźnika dla Polski była zbliżona do wielkości mediany tożsamego wskaźnika dla grupy krajów UE-10, jak i dla grupy krajów UE-15.

Kolejna część analizy obejmuje obszar energii w dziedzinie 6. Analizując kształtowanie się wskaźników dotyczących zużycia energii brutto (wykres 3) widocznym jest, że w porównaniu do grupy krajów UE-10 oraz UE-15 na początku, jak też na końcu przyjętego okresu badawczego wielkość zużycia energii brutto $\mathrm{z}$ odnawialnych źródeł energii dla Polski była większa od median tożsamego wskaźnika dla grupy krajów UE-10 oraz UE-15. Jest to sytuacja pozytywna, gdyż wskazuje, że Polska zaczyna przywiązywać coraz większą wagę do pozyskiwania energii ze źródeł odnawialnych oraz, że w porównaniu do innych krajów unijnych ma stosunkowo duży stopień jej wykorzystania.

Wielkość wskaźnika zużycie energii brutto - produkty naftowe dla Polski zarówno w 2004 roku, jak też w 2010 roku była mniejsza od wielkości mediany tożsamego wskaźnika dla grupy krajów UE-15. Podkreślić należy, że w 2010 roku w stosunku do 2004 roku wielkość zużycia energii brutto dla produktów naftowych w Polsce znacznie zmniejszyła się w stosunku do wielkości mediany tego wskaźnika dla UE-15. Wielkość analizowanego wskaźnika dla Polski zarówno w 2004 roku, jak też w 2010 roku kształtowała się znacząco poniżej wielkości mediany tożsamego wskaźnika dla grupy krajów UE-10.

Jak przedstawiono na wykresie 4 udział energii ze źródeł odnawialnych w produkcji energii elektrycznej w 2004 roku oraz w 2010 roku dla Polski był mniejszy niż wielkość median tego wskaźnika dla obu rozpatrywanych grup krajów. Sytuacja Polski w tym obszarze kształtowała się korzystniej w porównaniu do krajów z grupy UE-10, aniżeli do krajów z grupy UE-15. Podkreślić należy, że udział energii ze źródeł odnawialnych w produkcji energii elektrycznej na poziomie UE-25 w badanym okresie wzrósł, jednak w przypadku Polski był on znacznie mniejszy niż mediana tego wskaźnika dla grup krajów UE-10 i UE-15 zarówno w 2004 roku, jak też w 2010 roku.

Polska uzyskała dobre wyniki w obszarze skojarzonej gospodarki energetycznej (CHP) tzw. kogeneracji, czyli jednoczesnej produkcji użytecznej energii cieplnej i energii elektrycznej. Zarówno w 2004 roku, jak też w 2010 roku wielkość tego wskaźnika dla Polski była większa od wielkości median tożsamego wskaźnika dla obu analizowanych grup krajów. Zaznaczyć należy, że we wszystkich analizowanych krajach UE-25 zauważalne było stałe, ale powolne tempo rozwoju sektora jednoczesnej produkcji użytecznej energii cieplnej i energii elektrycznej. 

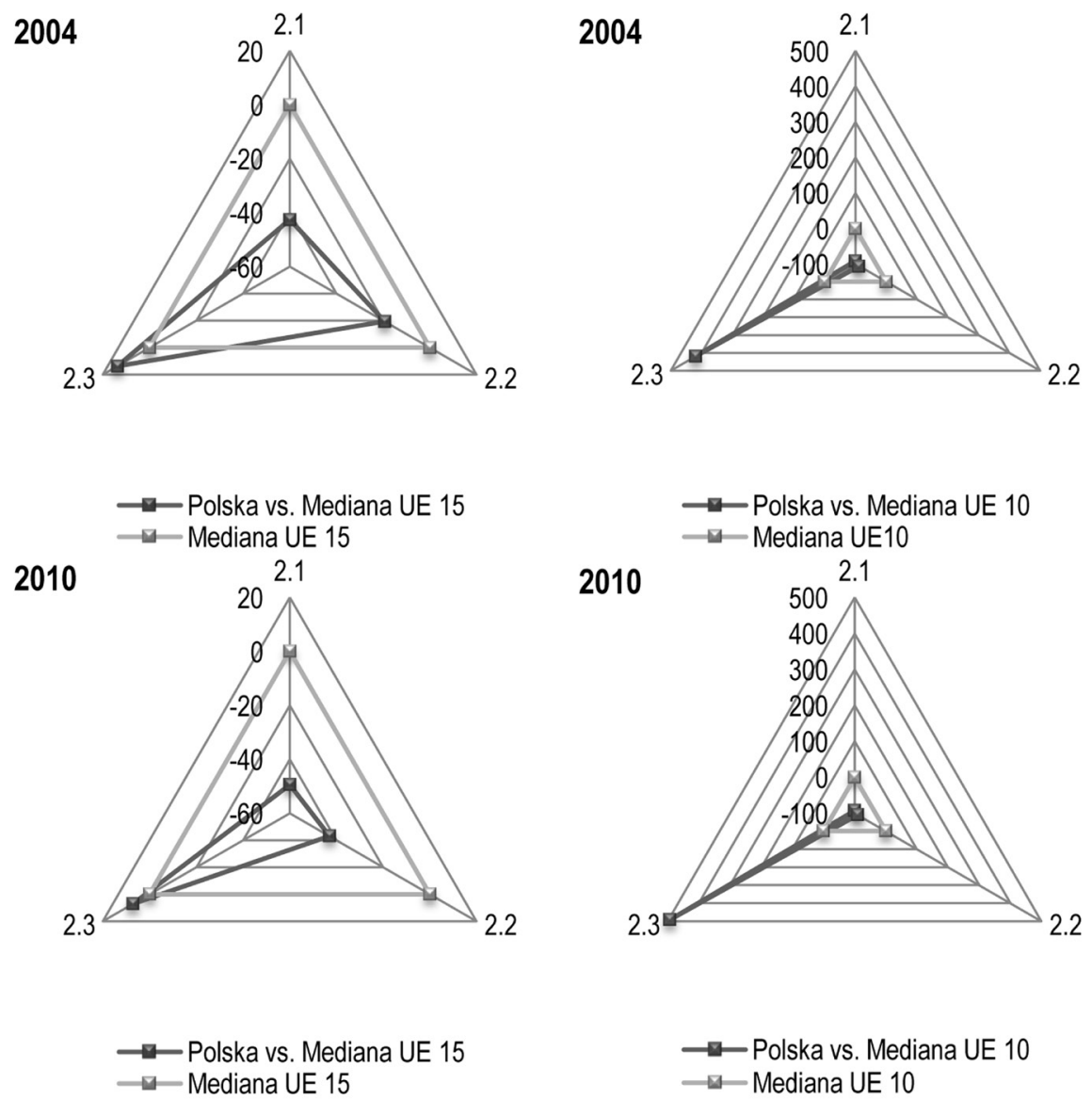

2.1. Zużycie energii brutto (1 000 ton ekwiwalentu ropy)

2.2. Zużycie energii brutto - produkty naftowe (1 000 ton ekwiwalentu ropy)

2.3. Zużycie energii brutto - odnawialne źródła energii ( 1000 ton ekwiwalentu ropy)

Wykres 3. Porównanie kształtowania się wskaźników z grupy zużycie krajowej energii brutto dla Polski z wielkościami median tożsamych wskaźników dla grup krajów UE-10 i UE-15 w latach 2004 i 2010

Źródło: Opracowanie własne na podstawie: Eurostat, http://epp.eurostat.ec.europa.eu/portal/page/portal/sdi/indicators (12.12.2013)

Polska w analizowanym okresie wykazywała wysoką zależność energetyczną w porównaniu do krajów z grup UE-10 i UE-15. Wielkość wskaźnika dla Polski kształtowała się powyżej wielkości median dla tożsamych wskaźników obu analizowanych grup krajów. W 2004 roku Polska wykazywała największą zależność energetyczną pośród wszystkich krajów UE-10 (wynosiła ona 85,26\%), zaś w porównaniu do krajów UE-15 większą zależność wykazywały jedynie Wielka Brytania (95,27\%) i Dania (147,34\%). W 2010 roku w po- 
równaniu do 2004 roku jedynie w przypadku 4. krajów z 25. analizowanych odnotowano spadek zależności energetycznej.

2004
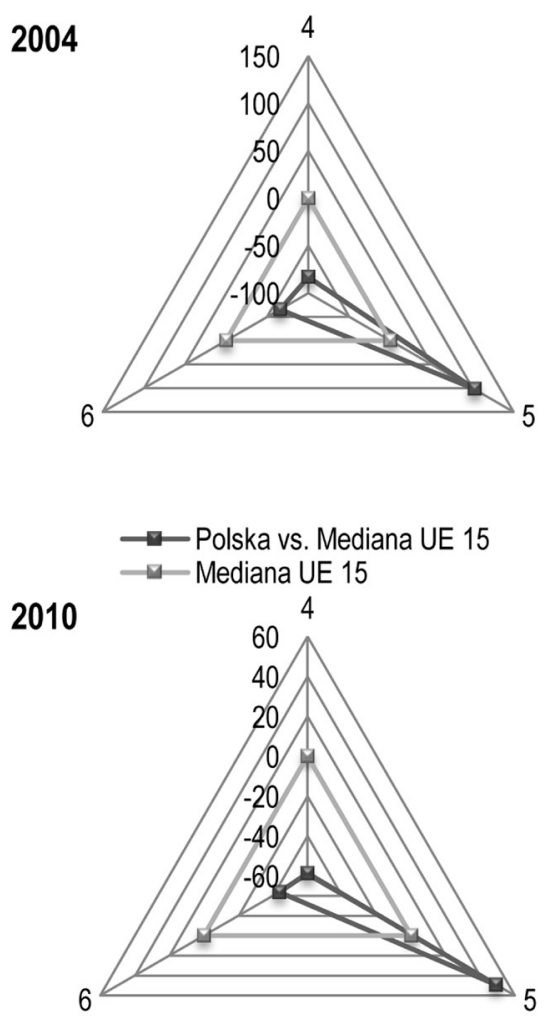

$\longrightarrow$ Polska vs. Mediana UE 15 $\longrightarrow$ Mediana UE 15
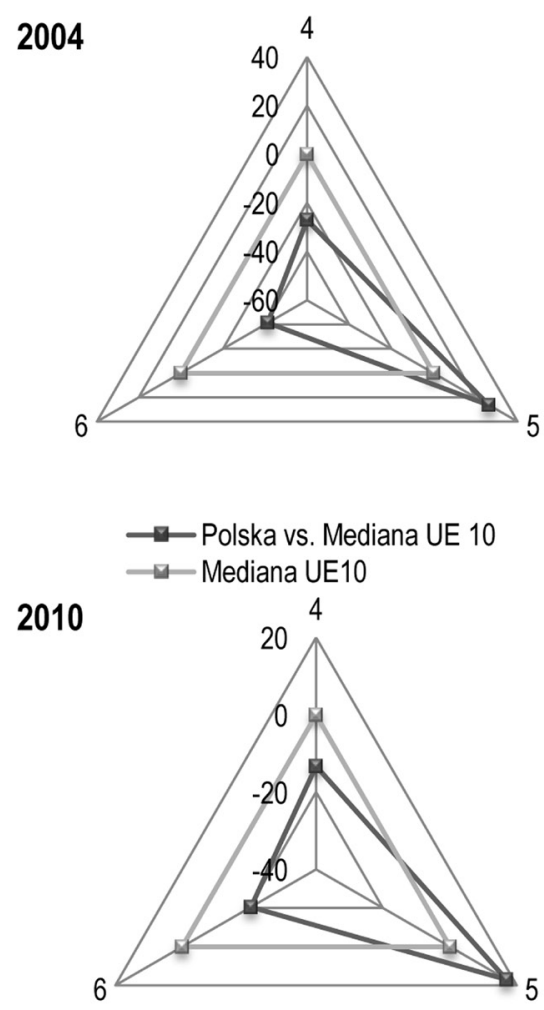

$\longrightarrow$ Polska vs. Mediana UE 10
$\rightarrow-$ Mediana UE 10

4. Produkcja energii elektrycznej ze źródeł odnawialnych (\% całkowitego zużycia energii elektrycznej)

5. Skojarzone wytwarzanie ciepła i energii elektrycznej (\% całkowitego zużycia energii elektrycznej)

6 . Zależność energetyczna (\%)

Wykres 4. Porównanie kształtowania się wskaźników: produkcja energii elektrycznej ze źródeł odnawialnych, skojarzone wytwarzanie ciepła i energii elektrycznej oraz zależność energetyczna dla Polski z wielkościami median tożsamych wskaźników dla grup krajów UE-10 i UE-15 w latach 2004 i 2010

Źródło: Opracowanie własne na podstawie: Eurostat, http://epp.eurostat.ec.europa.eu/portal/page/portal/sdi/indicators (12.12.2013).

Analiza danych ujętych w tabeli 3 obejmująca początkowe lata drugiego etapu realizacji zrównoważonego rozwoju, bazująca na wskaźnikach ujętych 
w strategii „Europa 2020” w obszarze zmian klimatycznych i energii pokazuje, że tendencje ukształtowane dla Polski z etapu pierwszego utrzymują się.

Tabela 3. Wskaźniki strategii „Europa 2020” z zakresu dziedziny zrównoważonego rozwoju „Energia i klimat" w latach 2010-2012

\begin{tabular}{|c|c|c|c|c|c|c|c|}
\hline \multirow{2}{*}{ WSKAŹNIKI GŁÓWNE } & \multirow{2}{*}{ CeL } & \multicolumn{2}{|c|}{2010} & \multicolumn{2}{|c|}{2011} & \multicolumn{2}{|c|}{2012} \\
\hline & & UE & POLSKA & UE & POLSKA & UE & POLSKA \\
\hline $\begin{array}{l}\text { Emisja gazów cie- } \\
\text { plarnianych (1990 } \\
=100)\end{array}$ & $\begin{array}{l}\text { zmniejszenie emi- } \\
\text { sji gazów cieplar- } \\
\text { nianych o } 20 \% \text { w } \\
\text { porównaniu z } 1990 \\
\text { roku }\end{array}$ & 85,74 & 88,09 & 83,07 & 87,56 & $b, d$, & $b, d$, \\
\hline $\begin{array}{l}\text { Udział energii ze } \\
\text { źródeł odnawial- } \\
\text { nych w końcowym } \\
\text { zużyciu energii brut- } \\
\text { to (\%) }\end{array}$ & $\begin{array}{l}\text { zwiększenie do } \\
20 \% \text { udziału ener- } \\
\text { gii odnawialnej w } \\
\text { ogólnych zużyciu } \\
\text { energii }\end{array}$ & 12,5 & 9,3 & 13,0 & 10,4 & $b, d$, & $b, d$, \\
\hline $\begin{array}{l}\text { Zużycie energii pier- } \\
\text { wotnej (mln ton } \\
\text { ekwiwalentu ropy } \\
\text { (toe)) }\end{array}$ & $\begin{array}{l}\text { zwiększenie efek- } \\
\text { tywności energe- } \\
\text { tycznej o } 20 \%\end{array}$ & 1653,6 & 96,0 & 1596,4 & 96,3 & 1583,5 & 93,3 \\
\hline
\end{tabular}

Źródło: Opracowanie własne na podstawie: Eurostat, http://epp.eurostat.ec.europa.eu/cache/Euro_2020/E2020_EN_ banner.html (13.02.2014).

Widoczny jest dalszy spadek emisji gazów cieplarnianych, wzrost udziału energii odnawialnej w ogólnym zużyciu energii ${ }^{14}$ oraz wzrost efektywności energetycznej. Oznacza to, że Polska zmierza w kierunku zrównoważonego rozwoju spełniając wymogi pozwalające przeciwdziałać zmianom klimatycznym, racjonalnie i efektywnie gospodarować energią, pozyskiwać energię w sposób przyjazny dla środowiska naturalnego.

\section{ZAKOŃCZENIE}

Problematyka dotycząca zmian klimatycznych i energii jest istotną częścią rozważań wpisujących się w koncepcję zrównoważonego rozwoju. Zrównoważony rozwój stanowi obecnie jeden z podstawowych paradygmatów rozwoju społeczno-gospodarczego, stąd też ważnym jest poświecenie szczególnej

${ }^{14}$ Zob. szerzej w: Mazur-Wierzbicka E., Zrównoważony rozwój energetyki odnawialnej w Polsce, [w:] D. Bochańczyk-Kupka, S. Swadźba (red.), Systemy gospodarcze i ich erwolucja. Aspekty mikro- $i$ mezoekonomiczne, Studia Ekonomiczne, Zeszyty Naukowe Wydziałowe Uniwersytetu Ekonomicznego w Katowicach, Katowice 2013, s. 246-251. 
uwagi każdemu z elementów go tworzących. Analizując kształtowanie się wskaźników z 6. dziedziny wyodrębnionej w ujęciu wskaźnikowym zrównoważonego rozwoju Unii Europejskiej, jak również uwzględnionych w obowiązującym dokumencie strategicznym UE „Europa 2020” zauważalnym jest, że kraje członkowskie w znacznej części dążą do spełnienia stawianych im wymogów wynikających $\mathrm{z}$ różnorodnych dokumentów unijnych z zakresu zmian klimatycznych i energii. Świadczą o tym zarysowujące się korzystne tendencje kształtowania się wskaźników z tego obszaru.

Polska w analizowanej dziedzinie prezentuje się korzystnie w stosunku do pozostałych krajów unijnych pod względem emisji gazów cieplarnianych, zdecydowanie niekorzystnie natomiast pod względem zużycia energii pierwotnej (w badanym okresie wystąpiła tendencja rosnąca, w odróżnieniu do tendencji charakterystycznej dla większości analizowanych krajów). Za trend pozytywny dla Polski uznać należy także wzrost udziału odnawialnych źródeł energii w końcowym zużyciu energii brutto (w 2004 roku w stosunku do 2010 roku zanotowano wzrost o 34,3\%). Jest to tendencja zauważalna dla większości krajów zarówno z grupy UE-10, jak i UE-15.

\section{BIBLIOGRAFIA}

Eurostat, http://epp.eurostat.ec.europa.eu/cache/Euro_2020/E2020_EN_banner.html (13.02.2014).

Eurostat, http://epp.eurostat.ec.europa.eu/portal/page/portal/sdi/indicators (12.12.2013).

Gabrusewicz T., Pomiar w zrównoważonym rozwoju - w poszukiwaniu wspólnej koncepcji, [w:] W. Czternasty (red.), Gospodarka Polski po akcesji do Unii Europejskiej. Wymiar finansowy, Zeszyt Naukowy Uniwersytetu Ekonomicznego w Poznaniu, Nr 207/2011.

Komisja Europejska, Europa 2020. Strategia na rzecz inteligentnego i zrównoważonego rozwoju sprzyjajacego wtaczeniu spotecznemu, COM (2005)2020, Bruksela 2010.

Komisja Europejska, Zrównoważona Europa dla Lepszego Świata: Strategia Zrównoważonego Rozwoju Unii Europejskiej, COM(2001)264, Bruksela 2001.

Mazur-Wierzbicka E., Zrównoważony rozwój energetyki odnawialnej w Polsce, [w:] D. Bochańczyk-Kupka, S. Swadźba (red.), Systemy gospodarcze i ich ewolucja. Aspekty mikro- $i$ mezoekonomiczne, Studia Ekonomiczne, Zeszyty Naukowe Wydziałowe Uniwersytetu Ekonomicznego w Katowicach, Katowice 2013.

Rada Unii Europejskiej, Odnowiona Strategia Unii Europejskiej dotyczqca Trwatego Rozwoju, Bruksela 10917/2006. 
